\title{
The Place of Astronomy in Roman Egypt
}

\section{Alexander Jones}

In 1855 an English clergyman, the Revd. Henry Stobart, returned from a sojourn of several months in Egypt bringing back with him various papyri and other antiquities. He sold the papyri to the British Museum, and the other artifacts to a Liverpool goldsmith named Joseph Mayer, who added them to the large and valuable collection of miscellaneous antiquities that he donated twelve years later to the City of Liverpool. ${ }^{1}$ Before parting with his acquisitions, however, Stobart had shown them to the Egyptologist Heinrich Brugsch. Brugsch was sufficiently interested in four wooden tablets with Demotic writing, bought and, allegedly, found at Thebes, to oversee the preparation of a facsimile which Stobart had printed as Plate $\Pi$ of a pamphlet of five large-format plates in Paris; and the next year Brugsch published a monograph in which he presented the tablets again in facsimile, but now with a translation and commentary. ${ }^{2}$ Brugsch arrived at an essentially correct insight into the nature of the Stobart Tablets, that they record in tabular form the motion of the planets over a succession of years, including the reigns of Trajan and Hadrian. 
The Stobart Tablets were the first direct evidence to come to light of the astronomical practices of Roman Egypt, independent of those authors such as Ptolemy whose writings were transmitted through the medieval manuscript traditions. For the better part of a century Brugsch's work on them drew practically no attention. In the meantime, however, a few more texts, both Demotic and Greek, of recognizably astronomical content turned up among the great hoards of papyri that were discovered or excavated in the late nineteenth and early twentieth centuries. Occasionally papyrologists enlisted the help of astronomers in trying to interpret these papyri. Thus when in the 1930s Frank Robbins found a fragment of a table containing numerals and names of zodiacal signs in Greek among the Michigan papyri, he joined Heber Curtis of the University of Michigan Observatory in making an edition and analysis which not only identified the fragment as part of an ephemeris or astronomical calendar in codex form, pertaining to the year $\mathrm{AD} 467$, but related it to an obscure text on the construction of such ephemerides preserved in several Byzantine astronomical and astrological manuscripts; and soon after, another historically-minded astronomer, J.K. Fotheringham, showed that the data in the Michigan ephemeris were computed using the Handy Tables of Ptolemy: a further rapprochement between archaeology and the medieval tradition. ${ }^{3}$ But this was an exceptional success. For the most part such astronomical papyri as were published before the 1940s were understood only superficially or not at all.

It was a chance conjunction that made possible a breakthrough in exploiting these documents. About 1933 a collection of papyri was offered for sale in Cairo, and it was bought by the Carlsberg Foundation, arriving in Copenhagen in 1936. By coincidence, O. Neugebauer, whose situation at the Mathematical Institute at Göttingen had become impossible because of his refusal to cooperate with the new Nazi government, was invited to take up a temporary appointment at Copenhagen. At this time Neugebauer was immersed in the study of Babylonian astronomy, but when H.O. Lange and A. Volten, the Egyptologists responsible for the Carlsberg papyri, consulted Neugebauer about two Egyptian papyri concerning astronomy in the collection, he undertook to collaborate on editing these texts. Volten also drew Neugebauer's attention to 
Brugsch's old paper on the Stobart Tablets as well as an analogous Demotic almanac on papyrus in Berlin, dating to the years 14 through 41 of Augustus. In this way Neugebauer was encouraged to undertake the study of Egyptian astronomical papyri as a potentially unified whole.

After he came to America in 1939, Neugebauer began investigating papyri written in Greek as well as Egyptian. Among the most significant of his earlier publications in this field was his analysis of an already published document, $P$ Rylands $1.27 .{ }^{5}$ He demonstrated that this text comprised instructions for generating a table of dates and positions of the moon at its times of least apparent speed, according to rules that had a clear relation to Babylonian methods known from cuneiform tablets of the Seleucid period, and also, as he soon afterwards discovered, to methods of astronomical prediction used by Tamil astrologers as reported by European scholars in the eighteenth and nineteenth centuries. ${ }^{6}$ The Rylands papyrus exposed to view a wholly unsuspected Greek astronomical tradition contemporary with Ptolemy, which, unlike Ptolemy's astronomy, had obvious ties to the other great traditions of the Near East and India.

Although his researches on astronomical papyri are not the best known of Neugebauer's vast oeuvre, no other department of the history of astronomy was so exclusively his. Among the highlights were his edition of the Greek horoscopes in collaboration with H.B. van Hoesen, detailed inventories of all known astronomical and astrological papyri and ostraca, and the monumental three-volume edition with R.A. Parker of Egyptian Planetary Texts. ${ }^{7}$ And right up to his death in 1990, whenever a papyrologist came across a fragment bearing numbers or astronomical terms, it was invariably referred to Neugebauer.

In what directions should this study progress after him? In part the answer lies in continuing the line of his work. Just over sixty astronomical papyri have been published to date, of which between fifteen and

4 Volten 1951; Swerdlow 1993: 145, 157; Neugebauer 1939; Neugebauer 1942.

5 Neugebauer 1949.

6 Neugebauer 1952.

7 Neugebauer \& van Hoesen 1959; Neugebauer 1962: 383-391; Neugebauer \& van Hoesen 1964; Neugebauer \& Parker 1966-1969. you by | New York University 
twenty have individually made a significant contribution to our understanding of Roman era astronomy. Numerous others undoubtedly await discovery and publication in the museums and libraries of Europe and elsewhere. The sheer size of some of the collections, the lack of inventories, and likewise the lack of enough papyrologists makes the discovery of documents of a specific kind often a matter of luck. One of the greatest of the collections, that of the Oxyrhynchus papyri excavated between 1896 and 1906 by B.P. Grenfell and A.S. Hunt, has been inventoried, and I am at present editing the astronomical texts therein. ${ }^{8}$ The number of new publishable fragments from Oxyrhynchus alone will roughly double the corpus available for study. And as the new texts deepen our understanding of the varieties and technical content of the astronomical documents, it becomes necessary to reexamine those that were published before, and to revise the conclusions that were drawn from them.

But as our understanding of the mathematical and astronomical aspects of the papyri deepens, and as we become more confident in our ability to say what kinds of documents were and were not present in the papyrus record as a whole, we are also in a better position to address other questions that Neugebauer and the other early investigators only touched upon. What purposes did the astronomical documents serve? Who wrote and used them? And what course did the evolution of this technical practice follow? We have two possible starting points for exploring these questions: the contents of the documents, and their provenance. Both, despite certain pitfalls, have valuable information to yield, but it turns out to be advantageous to begin with a survey of the kinds of astronomical document that we find on papyri and other archaeologically recovered media, and their relative frequency. ${ }^{9}$

Superficial inspection suggests a first division of the fragments into three general classes: numerical tables, horoscopes, and other kinds of text. The horoscopes are records of the positions of the sun, moon and planets, and of the ascendant point of the ecliptic computed for a specific date and time (the birthdate of a person, who is often named in the

8 P Oxy LXI.4133-4300, to be published as Astronomical Papyri from Oxyrhynchus. The introduction to this edition will include a more technical discussion of the varieties of astronomical papyri and their contents.

9 The term 'papyri' should be understood in this paper to encompass ostraca and wooden boards, except where the conted refers to the specific writing medium. 
document). These are astronomical texts insofar as the data they contain are primarily astronomical in nature. Of course they were intended to supply the basis for an astrological forecast, but astrological interpretations and predictions almost never appear on the actual horoscope. About 85 horoscopes in Greek, and another eight in Demotic, have been published; the unpublished Greek horoscopes from Oxyrhynchus will add another 65 to the total. ${ }^{10}$

Positions of the heavenly bodies also appear in tabular form on papyri, computed now not for an arbitrary given date but at regular intervals of time or for a succession of dates determined by some astronomical criterion. There are several recurring formats. The ephemerides, of which the Michigan papyrus published by Curtis and Robbins is typical, are laid out according to the months and days of a civil calendar (either the Alexandrian or Julian), and tabulate daily positions of the sun, moon, and planets, equivalent dates according to other calendars, and, in some ephemerides, evaluations of each day as auspicious or inauspicious. We have fragments of about a dozen ephemerides. Sign-entry almanacs list the dates when each planet crosses into a new zodiacal sign over a span of several years. This is a very common format, with about twenty extant specimens including the Stobart Tablets. Other kinds of almanac give planetary positions at fixed intervals of five days, or the positions at the beginning of each month.

Now when Brugsch studied the Stobart tablets in the 1850s, he assumed that their statements that such-and-such a planet was in suchand-such a zodiacal sign on such-and-such a date were records of observation. ${ }^{11}$ It was one of Neugebauer's earliest insights into this kind of almanac that at least some of the recorded positions were computed rather than observed, since they included situations when the planets were invisible because of their proximity to the sun. Initially he guessed that a combination of observations and theoretical calculations was at work, but he subsequently discarded this hypothesis because the growing corpus of ancient astronomical records on the one hand failed to turn up unambiguously observational records of the kind needed, and on the

10 Neugebauer \& van Hoesen 1959; Baccani 1992.

11 Brugsch 1856: 20. In an addendum (63-64) Brugsch reports Biot's scepticism concemıng the putative existence of a programme of regular observation in Roman Egypt. 
other hand revealed that computational techniques had existed in Roman Egypt that were capable of generating planetary positions and dates of sign entry. ${ }^{12}$ By now it can be asserted with confidence that all Greco-Egyptian almanacs, ephemerides, and horoscopes contain exclusively computed astronomical data. In general, the horoscopes and almanacs would have been produced within a few decades after the dates to which they refer, whereas the ephemerides at least in some instances were made before the dates covered, since the evaluation of good-luck and bad-luck days would only be useful in advance.

Along with the ephemerides and almanacs, we have about thirty specimens of the tables used in the intermediate steps of calculating positions of the sun, moon, and planets. Some of these list computed epoch positions corresponding to widely-spaced consecutive occurrences of a single stage of the anomalistic cycle of the body in question, while others do not themselves contain positions pertaining to specific dates. The half dozen or so sets of fragments from Ptolemy's Handy Tables that we have on papyrus belong to this class. Since the astronomical data in the almanacs and ephemerides were presumably computed using these sorts of table, I refer to this group as 'primary' tables, and the almanacs and ephemerides as 'secondary' tables.

In comparison to the more than one hundred tables and the more than one hundred and fifty horoscopes, we have fewer than forty astronomical prose texts on papyrus. The greater part set out rules either for constructing tables or for using them, a category that we may call 'procedure texts'. $P$ Rylands 1.27 is a procedure text, one of the few that is well enough preserved to make much connected sense. We have two canons of lunar eclipses, one (P. dem. Berlin 13146 + 13147) in Demotic from the early first century B.C. in which the descriptions of the eclipses are mostly forecasts butsome remarks seem to derive from observations, ${ }^{13}$ and the other ( $P O x y$ LXI.4137) in Greek from the first century of our era, which seems to be entirely forecasts. Only a handful of Roman-era texts can legitimately be characterized as 'theoretical'. The most substantial of these are P. dem. Carlsberg 1, a commentary in Hieratic and Demotic on the astronomical

12 Neugebauer 1942: 240-242; Neugebauer \& Parker 1960-1969: 3.236; Neugebauer 1975: 789-792.

13 Neugebauer, Parker \& Zauzich 1981? rought to you by | New York University 
picture and texts known from the cenotaphs of the second-millenium B.C. pharaohs Seti I and Ramses IV; P Iand V.84, a fragment of a Greek text on spherical astronomy; and P Oxy LXI.4133, a column and a half of a Greek treatise concerning observations and anomalistic periods of Jupiter, probably by Menelaus of Alexandria.

Can the chronological distribution of astronomical papyri tell us anything about the evolution of astronomical practice in Roman Egypt? For this line of investigation it is helpful that most of the horoscopes and a large proportion of the astronomical tables can be dated from their contents. The earliest known date for which a papyrus horoscope in Greek was cast is $10 \mathrm{BC}$, and the latest is $\mathrm{AD} 508 .^{14}$ The handful of Demotic horoscopes on ostraca begin with one cast for $38 \mathrm{BC}$, still in the reign of Cleopatra VII, and the latest, apparently a school text rather than an authentic personal horoscope, is for AD 171; we also have three horoscopic coffin lids from the second century..$^{15}$ The nativity dates of horoscopes are of course not to be equated with the date when the computations were made, and this date in turn may precede the date when the extant document was written. An astrologer's customers may have included old men and women as well as the parents of newborn children, as was the case with the extensive practice of the second-century Antiochene astrologer Vettius Valens. ${ }^{16}$ One may perhaps estimate that the frequency of nativity dates (Fig. 1) is an index of the popularity of astrology about twenty or thirty years later.

The trend for the body of horoscopes as a whole appears as a steady increase in numbers from the end of the first century $B C$ to the second half of the second century of our era, after which they remain at about the same level through the second half of the third century, then declining through the course of the fourth century, with only sporadic horoscopes thereafter. Interestingly, the horoscopes from Oxyrhynchus show a different distribution from the rest, with a more uniform rate up to the end of the second century, a very large peak in the third century, and then a return to lower frequencies. In fact were it not for the surge of Oxyrhynchite horoscopes in the third century, the overall decline would

14 Neugebauer \& van Hoesen 1959; Baccani 1992.

15 Neugebauer 1943; Neugebauer \& Parker 1968; Parker 1984.

16 Neugebauer \& van Hoesen 1959: 177-1\% 9 .t to you by | New York University 


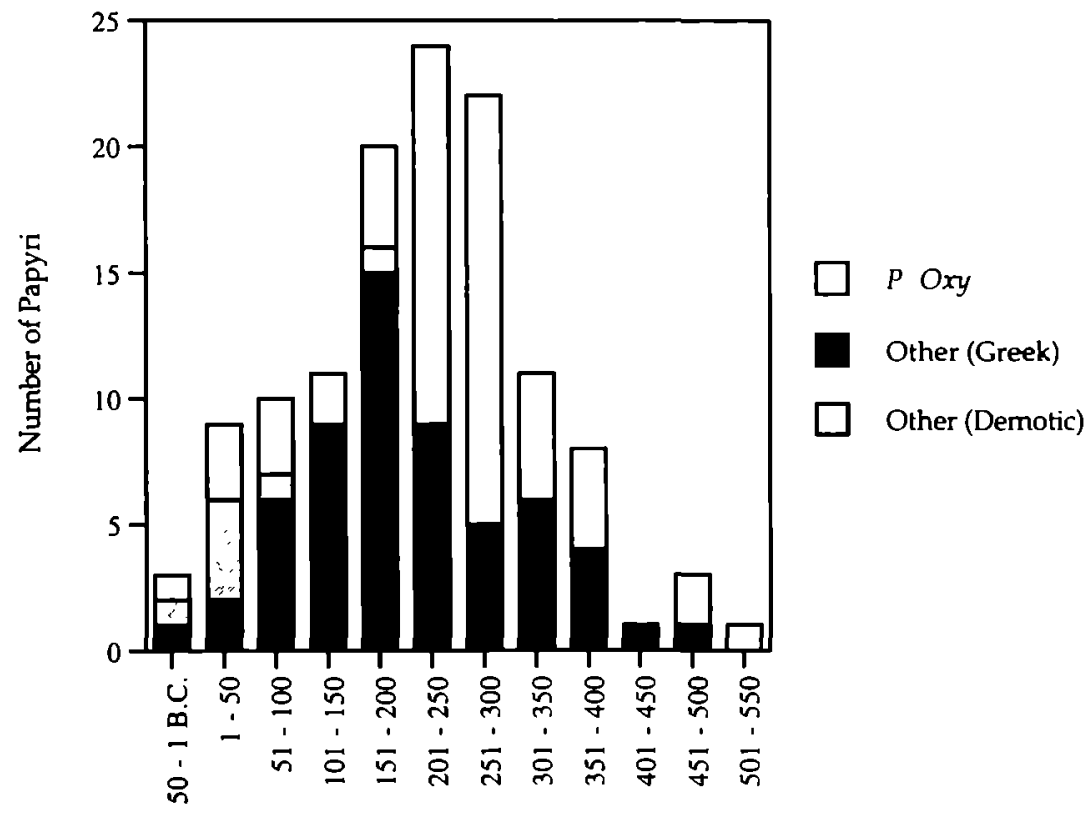

Latest Natıvity Date (by half century)

Fig. 1. Chronological distribution of documentary horoscopes by nativity date.

set in immediately after AD 200. Similar trends govern the astronomical papyri (Fig. 2), as one would expect if, as I am going to argue, they are artifacts of the same astrological activity that produced the horoscopes. The agreement is the more significant since the horoscopes would usually have been owned (and discarded) by the people to whom they refer, and hence they are less subject than astrologers' papers to the chronological clumping that can happen when excavation hits upon the debris of a large personal archive.

But the full significance of these patterns is difficult to appraise unless they can be gauged against the chronological distribution of other categories of papyri from Oxyrhynchus and elsewhere. The relative frequency by date of published papyri of a particular genre reflects, after all, not only the variations in the extent to which they were originally

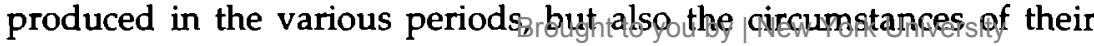
preservation and the criteria used by modern editors int seledtiagcwhich 


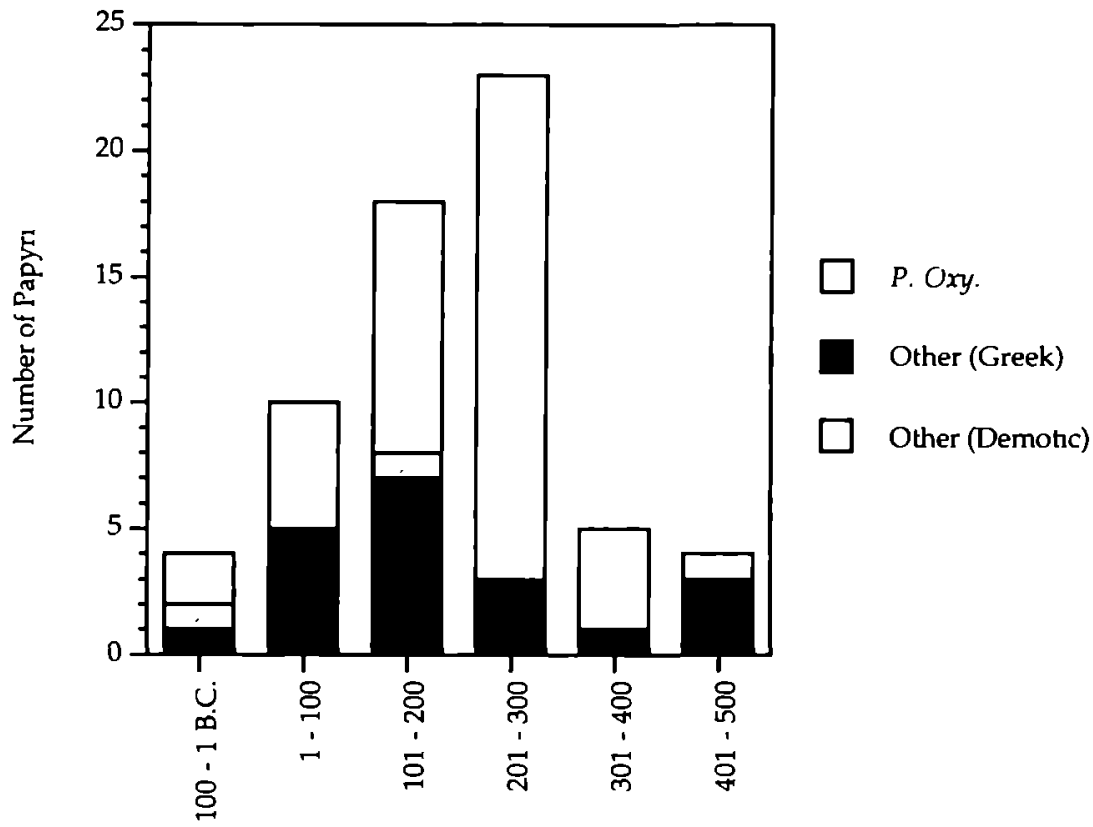

Latest Date of Contents (by century)

Fig. 2. Chronological distribution of astronomical papyri by latest date covered.

texts to publish; and it is only by comparing the distribution of papyri of a particular genre with other major categories of text or with the papyrus record as a whole, and preferably on a site-by-site basis, that we can hope to isolate the factors that contribute to the rises and falls in our counts. Unfortunately, reliable and statistically meaningful estimates of the relative numbers of papyri from the various centuries or half-centuries are difficult to come by. Many modern collections of papyri are too small to yield useful statistics, and provenance of the texts is often unknown. The large collections have only been partially edited, and both because of the lack of inventories and the inclinations of the papyrologists - few genres of text have been exhaustively sought out in these collections and published regardless of their date.

We can see the difficulties more clearly by considering just the astronomical and horoscopic papyri fremugyorhynghusewhighnowaccount for more than half of the known papyri of these genresuBecairasedof the 
exceptionally thorough inventory carried out in recent decades by the Egypt Exploration Society, it was possible to identify and edit probably the great majority of these varieties of text from the vast array of storage boxes containing Grenfell and Hunt's finds. ${ }^{17}$ In this instance the editor (myself) will have introduced no chronological bias in the selection of texts. But the same can be said for scarcely any other genre represented in the sixty volumes of The Oxyrhynchus Papyri published to date, which may account for less than half the papyri that will eventually be judged publishable from the collection. ${ }^{18}$ Any statistics derived from the series in progress may tell us as much about the tastes of twentieth-century editors as about those of the ancient Oxyrhynchites. For what it is worth, the general trend of the published documentary papyri from Oxyrhynchus may be seen from Fig. 3, which compares frequencies specifically of regnal dates in documents, derived from the indices of twenty volumes of The Oxyrhynchus Papyri.

For the first two tabulated half centuries the counts are low, presumably because most documents of this age were below the damp level of the site and so perished long ago; it is unlikely that this early period will have been underrepresented by modern editors. Afterwards, numbers remain fairly steady at least until the end of the third century, which marks the end of the period during which regnal year datings can be considered representative of the documents as a whole. Comparison of Fig. 3 with the data from Oxyrhynchus in Fig. 1 does at least show that the scarcity of horoscopes and other astronomical papyri dated before the first century of our era merely reflects the poor record of survival of documents in general from this period. In other words, for tracing the first diffusion in Egypt of astronomy, whether applied to horoscopy or not, the Oxyrhynchus papyri are of little value. Secondly, horoscopes pertaining to people born between $\mathrm{AD} 1$ and 50 are roughly as numerous as from the subsequent three half-centuries, even though the first half of the first century is not well represented among the general body of documents. This circumstance confirms our estimate that the horoscopes

17 There are of course numerous papyri from Oxyrhynchus in other collections, in particular those recovered by the Italian campaigns subsequent to Grenfell and Hunt's. These are as yet much less thoroughly surveyed.

18 An exception might be made for certain small literary categories, such as the Greek lyric poets whose fragments were exhaustively sought oum by E. Lobier.
Authenticated 


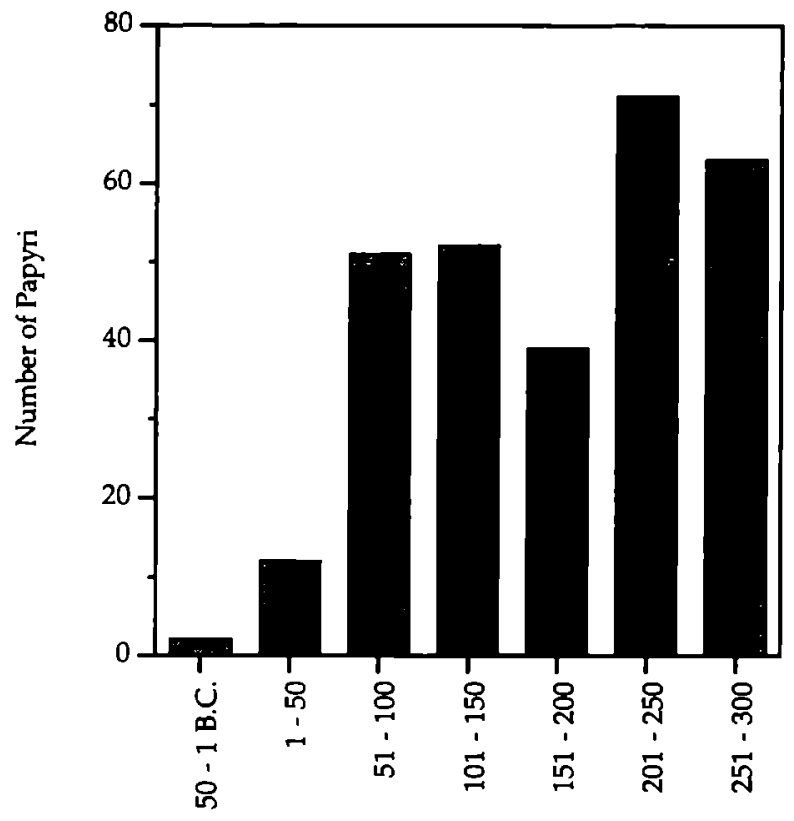

Latest Regnal Year (by half-century)

Fig. 3. Chronological distribution of documentary P. Oxy. by latest date covered

were written (or at least discarded) on average about a generation after the nativity dates. And lastly, the surge in horoscopes and astronomical documents of the third century, since it lacks any counterpart in Fig. 3, seems to indicate an actual intensification of astronomical and horoscopic activity at Oxyrhynchus about that time - but this might prove to be a mirage if the unpublished Oxyrhynchus papyri eventually turn out to include a great mass of third-century documents that have merely not attracted proportionate interest in the editors. ${ }^{19}$

19 Statistics for literary P Oxy are subject to the same kinds of bias, and in addition are almost entirely based on palaeographical estimates of dating. The extensive authorby-author tabulations in Krugger 1990: 313-354 show in most instances a pronounced peak in the second century.

Brought to you by | New York University 
Although we cannot locate the beginning of this activity in the papyrus record, we can see certain indications of evolving conventions and methods. On the whole, the horoscopes maintain a uniform format. One noteworthy feature is the survival of dating by the old Egyptian calendar in horoscopes as late as AD 207, usually in conjunction with the civil Alexandrian date. The Egyptian calendar was used in nearly all primary tables throughout the documented period on account of its convenient years of constant length. This purely technical use of the Egyptian calendar as a means of representing elapsed time between astronomical phenomena reinforces our segregation of the tables into 'primary' and 'secondary' classes, since among the secondary astronomical tables, that is, the ephemerides and almanacs, the Egyptian calendar is much rarer: it last appears in a sign-entry almanac on wooden tablets for years about AD 101, whereas the civil Alexandrian calendar is more often used even in tables pertaining to the reign of Augustus. On the other hand, the Roman calendar is assigned a column in ephemerides from the reign of Augustus right to the late fifth century, and from the fourth century ephemerides begin to be laid out according to the months of the Roman rather than the Alexandrian calendar. The regular incorporation of the Roman calendar in the earliest ephemerides is a hitherto unnoticed exception to the rule that before the fourth century Roman dates only appear in papyri connected with Roman institutions and government. ${ }^{20}$

Another difference between early and late ephemerides is in format: the earlier ephemerides give only sparse data for the motion of the planets in the form of a tabular almanac above the main ephemeris, while the later ones reserve a column for the daily longitudes of each planet. ${ }^{21}$ Sign-entry almanacs, although fairly stable in format as long as they continued to exist, seem to have dropped out of use a little after the third century, about the same time that we get our first examples of almanacs tabulated at fixed intervals of five days.

I believe that some of these changes in format can be explained in terms of a contemporary change in the computational methods. Although only a minority of the primary astronomical tables can be dated

20 Cf. Sijpesteijn 1979: 230-232. The published ephemerides from late antiquity, which are arranged by the Roman calendar, are not mentioned in his article.

21 Jones 1994: 63. 
by contents, they can be segregated into an older and a newer methodology. The older tradition derives from the Babylonian mathematical astronomy of the last four centuries BC, and applies arithmetical methods to predicting the positions of the heavenly bodies. The new tradition is that of Ptolemy's Handy Tables, which apply trigonometric functions to represent the apparent motions consequent on astronomical hypotheses involving uniform circular motion. Ptolemy published his tables not long after AD 150, and their use can be demonstrated in papyri from the middle of the third century on. One of the consequences of using Ptolemy's tables is that it becomes more natural to tabulate planetary positions at fixed intervals rather than attempting to determine the dates when they cross the boundaries of zodiacal signs; and this is essentially the difference between the older and newer ephemerides and almanacs. ${ }^{22}$ However, the older arithmetical methods of prediction did not immediately disappear with the advent of Ptolemy's tables. Their last known use is in an ephemeris for AD 348, two centuries after Ptolemy. In fact, the wonder is not that the arithmetical methods persisted so long, but that the much more technically difficult Handy Tables should have received such a broad reception among people who to all appearances were not competent to appraise their superiority.

For the overwhelming impression given by the papyri is of a predictive astronomy, concerned with calculating the positions of sun, moon, and planets and the configuration of the heavens at particular times. Twoother divisions of astronomy, both practised in other environments in antiquity, seem to have been almost completely neglected in provincial Egypt: the routine of regular observation that formed a major component of Mesopotamian astronomy, and the theoretical concern with analysis of observations and explanation of planetary motion by means of kinematic geometrical models that was characteristic of Hipparchus's work and Ptolemy's Almagest. Only the Menelaus fragment pertains to this last tradition; and the two observations of Jupiter that it discusses (probably made at Rome), together with certain past-tense remarks in the Demotic eclipse canon and a Theban ostracon recording a solar eclipse of AD 601, ${ }^{23}$

22 Nevertheless a small group of third-century sign-entry almanacs from Oxyrhynchus have turned out to be computed by Ptolemy's tables.

23 Allen 1947. 
are the only archaeologically recovered observational reports from Egypt during the entire period of Greek and Roman rule.

But if the astronomical papyri have a limited scope by the standard set by Ptolemy or by the Babylonian astronomers of the last four centuries $\mathrm{BC}$, they are at the same time more numerous and more technically advanced than the extant papyri representing other sciences. The second edition (1965) of Pack's inventory of literary papyri lists, for example, some twenty mathematical papyri (i.e. about half the number of astronomical texts and tables known at that date). ${ }^{24}$ Most of these concern basic arithmetic and mensuration, and none is more advanced than Euclid's Elements. The papyrus record for the other mathematical sciences, such as optics, harmonics, and technical geography, is negligible. Writings on physical science were evidently not much read by those literate Greeks of Oxyrhynchus and the other Egyptian towns who have left us so many valuable fragments of literature. ${ }^{25}$

The reason for astronomy's greater presence in the papyrus record is that it formed part of the equipment of practical astrology. That many of the astronomical papyri were owned by astrologers has long been taken for granted, but the argument has never been fully worked out. ${ }^{26}$ In the first place, we know that many astrologers were active in Egypt throughout the Roman period, because they have left their traces in the horoscopes and in a number of strictly astrological papyri that is comparable to the size of the astronomical corpus. Secondly, the kinds of predicted data supplied by the astronomical texts and tables on papyrus coincide with the requirements of practical astrology. The zodiacal signs occupied by the sun, moon, and planets at the birth of a customer are readily obtained from a sign-entry almanac, and the primary tables would provide for the de luxe horoscopes that utilized precise planetary positions in degrees and minutes. The ephemerides with their columns for auspicious and inauspicious days are manifestly directed to catarchic astrology, which sought to prescribe the best times

24 Pack 1965.

25 For readers and owners of manuscripts in Oxyrhynchus, see Turner 1952; 1956.

26 Baccani 1992: 29-37, discusses the possible relationship between the astronomical and astrological papyri, but without taking consideration of the contents of the papyri. 
for initiating activities; and the phenomena forecast in the eclipse canons, such as the directions of obscuration at the key stages of each eclipse, are familiar from Hephaestion of Thebes and John Lydus, as well as the Mesopotamian omen texts, as the data from which one made general prognostications about the welfare of countries and their rulers. So far as we know, computations of planetary positions or eclipse phenomena had no practical application outside of astrology in antiquity, and the character of much of the predicted data would have been valueless for the purely scientific concerns that in any case are so poorly attested in the papyri.

So the conclusion that these were astrologers' papers would be unavoidable even if we had noevidence from provenance to link astronomical texts to astrological activity. And indeed such evidence is not available for most of the papyri, even when they were acquired by archaeological excavation rather than through dealers. The Oxyrhynchus papyri, for example, were recovered by Grenfell and Hunt from the rubbish heaps of the ancient town, after digging in other parts of the site had failed to yield anything. ${ }^{27}$ They were thus found, not where they were originally written and used, but where they had been deliberately discarded in antiquity. And even this information is lost to us because Grenfell and Hunt did not leave a clear record of the correlation between the excavated sites and their inventory numbers. Groups of fragments collected under one inventory number, or with nearby numbers, may be an indication of an 'archive' of personal documents found where they had been discarded together by their owner, but since some sorting of fragments seems to have gone on between the digging and the filing, even such meagre evidence of collocation that we have must be used with caution.

But the direct link between astronomical and astrological documents that Oxyrhynchus fails to supply may be sought with more success elsewhere. In 1938 an Italian archaeological team working under A. Vogliano at Medinet Madi, the site of the ancient town of Narmuthis in the Fayum, while excavating the temple of the serpent goddess Ermuthis, came upon a small room containing more than 1500 ostraca inscribed in Demotic and Greek. ${ }^{28}$ The ostraca were deposited in the

27 See E.G. Turner, in James 1982: 161-178.

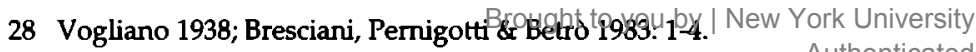


Cairo Museum, and have since completely vanished, perhaps destroyed by water seeping into the basement where they were stored. Fortunately, photographs were taken before this calamity, and a project of publication is now under way.

The contents of the ostraca reflect the activities that occupied the temple priests during the second century of our era. The majority of the texts pertain to scribal training, in both languages, but there is also a significant number that attest to the temple's having been a centre for astrology, especially horoscopy. Among the unpublished ostraca are both astronomical and astrological texts, as well as at least one text that sets out the duties of an astrologer-priest. ${ }^{29}$ Recently D. Baccani has published several Greek ostraca from the Medinet Madi find that bear horoscope notes, consisting of the date and time of birth of the customer alone. $^{30}$

The fact that most of the documents surviving from the temple of Ermuthis are mere ostraca limits the length and range of texts that we can expect to find, but this defect is compensated by the unusually exact knowledge we have of their provenance. By contrast, although another Italian excavation led by C. Anti at Tebtunis discovered in 1931 the remains of a library or archive in the temple of the crocodile god Sobek alias Suchos, large numbers of papyrus texts from other caches in the temple environs came into the hands of dealers, and these can be traced only imperfectly in the several museum collections that acquired them over four decades. ${ }^{31}$ In particular the core of the Carlsberg collection, which includes four published astronomical papyri, is known to derive from the Sobek temple, although this origin cannot generally be proved for each single papyrus. ${ }^{32}$ And there are known to be about 200-300

29 Baccani 1992: 50-51.

30 Baccari 1989.

31 The evidence, which is primarily internal, is reinforced by numerous instances of fragments from single papyrus rolls being divided among more than one modem collection, for example the Demotic herbal P. Tebt. Tait $20+P$. Carlsberg 230: Tait 1977: vii; Botti 1936; 1955; Volten 1951; Frandsen et al. 1991: 2.

32 It is also not clear whether any of the (apparently several) caches of papyri found in and about the temple of Tebtunis could be characterized as the temple 'library' rather than priests' personal archives; see the cautious remarks or Tait 1992:306-307. 
fragments of Demotic astrological texts among the unpublished Carlsberg papyri. ${ }^{33}$ Volten projected an edition of these texts with $\mathrm{G}$. Botti, but it was never carried out, and like most of the ostraca from Medinet Madi, the astrological papyri from Tebtunis are still awaiting a demotic papyrologist's attentions.

The texts from these two sites take us a big step beyond the mere confirmation that the users of the astronomical texts were chiefly astrologers. They also situate these astrologers within the temples. There is, in fact, more evidence of a similar character identifying Egyptian temples as a locus for astronomy and astrology. Recently E.A.E. Reymond has proposed to identify large parts of the large collection of Demotic papyri in the Austrian National Library in Vienna as remains of temple libraries from the temple of Sobek in Dimêand another north-west Fayumic temple of Sobek in or nearCrocodilopolis, and these would appear to includeboth astrological and, perhaps, astronomical texts of the Roman period. ${ }^{34}$ The origin of these papyri in these temples, however, is less firmly established than that of the papyri from Medinet Madi and Tebtunis. ${ }^{35}$

Secondly, we know of six Egyptian temple ceilings that have or had representations of the signs of the zodiac. ${ }^{36}$ Unlike other features of Egyptian pictures of more or less astronomical content, such as the decans, constellations, and planets, the zodiac is a clear sign of influence from astrology, although of course the presence of a pictorial motif cannot be regarded as proof that the activity from which the motif was derived was actually carried out in the same place.

Finally, we may wish to take into account the inferences that Cumont drew in his L'Égypte des Astrologues from the Greek astrological literature. ${ }^{37}$ These texts are mostly by authors of the Roman period who have no obvious affiliation with priesthoods, and the ancient and medieval manuscript traditions that transmitted them to us are no more visibly

33 Frandsen et al. 1991: 7. Other astrological papyri from the Tebtunis temple, mostly unpublished, have been identified in the British Museum (Andrews 1992: 13-14), Lille (Chauveau 1992), and Florence (Manfredi \& Neugebauer 1973).

34 Reymond 1976: 21-30; 1983: 53.

35 Tait 1992: 306 n. 18.

36 Neugebauer \& Parker 1960-1969: 3. 204.

37 Cumont 1937: 15, 113-114, 124-125. Brought to you by | New York University 
connected with temples than the traditions of other technical subjects or literature. Yet Cumont believed that the data on social conditions that he was able to extract from the interpretative element in the astrological treatises revealed a perspective in which priests and cult occupied the foreground, while social and political institutions that were at the greatest remove from the temple were in the hazy background; in particular, Cumont writes of the 'almost total ignorance of the interior life of the Greek cities'. ${ }^{38}$ And when professions appear listed together in these texts in relation to astrological characterizations and predictions, he pointed out that the astrologers are frequently numbered among priests, augurs, haruspices and the like. ${ }^{39}$ But Cumont's appraisal of the evidence from the astrological literature is rather subjective and supported by only a selection of cited passages, and so perhaps should be treated with caution.

Can we identify, within the hierarchy of the Egyptian temples, which persons were the astrologers? A famous passage in Clement of Alexandria's Stromateis (VI 35ff.) vividly describes the ritual procession of the Egyptian priests. First marches the ódós or 'chanter', who is followed in order by priests called ஸробкó

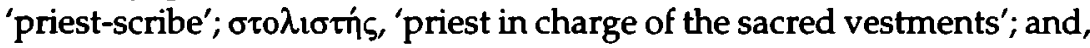

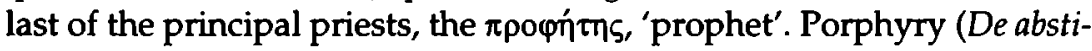
nentia IV 8), paraphrasing the first-century Stoic Chaeremon of Alexandria, gives nearly the same list, minus the 'chanters' and with slight variants on the titles of the priest in charge of the sacred vestments and the 'hour-watcher', who is here called ipohópos. In Clement's account we read that the 'hour-watcher' processes carrying objects called

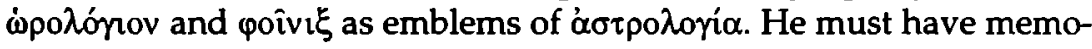

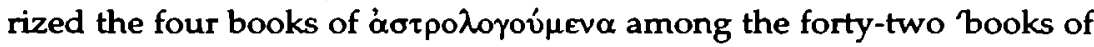
Hermes' which are, respectively, first 'on the orderly arrangement of the apparent fixed stars'; secondly 'on the placement [ $\tau \alpha \xi^{\prime} \zeta$ ] of the sun and moon and on the five planets'; thirdly 'on the conjunctions and phases of sun and moon'; and fourthly 'on the risings' ${ }^{40}$ A further indication of

38 Cumont 1937: 72.

39 Cumont 1937: 124 n. 5.

40 I accept as probable Gruppe's transposition of the phrase describing the second book here from the description of the books mastered by the priestiscribity. 
the astronomical competence of the Egyptian priests is found in two Hellenistic Greek papyri, $P$ Hibeh I.27 from the third century and $P$ Par 1 from the second century $B C$, which have almost identical passages

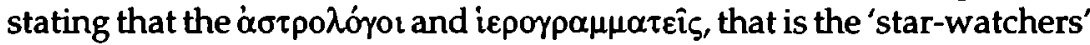
and the 'priest-scribes', use a combination of lunar months, the 365-day Egyptian year, and stellar risings to establish the dates of religious

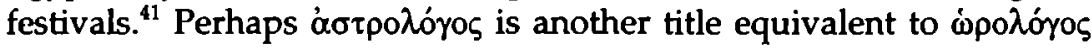
and $\dot{\omega} \rho \circ \sigma \kappa o ́ \pi o s$.

The identification of the 'hour-watchers' with the priests responsible for astrology, as we understand the word, has generally been taken for granted; Cumont in particular asserts that these priests were in charge of the administration of the calendar, extending their scope from establishing the feast days todetermining the auspicious and inauspiciousdays of catarchic astrology, and finally to the field of horoscopy. ${ }^{42}$ This may all be true, but it should be observed that what Clement terms $\alpha \sigma \tau \rho \lambda o$ jí $^{\alpha}$, as contained in the four 'books of Hermes', has no overt astrological content; as Neugebauer has shown, the books listed by Clement very likely hark back to the New Kingdom, and in particular these astral books pertain to an Egyptian astronomy that long predates the coming of astrological concepts from Mesopotamia to Egypt. ${ }^{43}$ The hieratic and demotic papyrus $P$ Carlsberg 1, which was copied in the second century of our era but comments on astronomical inscriptionssurviving in monuments from the second millenium $B C$, is a concrete witness to the survival of this old Egyptian astronomy in the Roman period. Again, one of theobjects carried by the 'hour-watcher' in procession, the poivi $\xi$ or 'palm', was convincingly identified by Borchardt as a kind of sighting instrument of which specimens are extant from pharaonic times; this was confirmed when Spiegelberg found that the latter instrument's Egyptian name was 'palm rib of the man concerned with time'. ${ }^{44}$

An argument might be made that the traditional Egyptian astronomy concerned primarily with time-keeping and calendar and the newer predictive astronomy tied to astrological prognostication were the do-

41 P Hibeh I.27 col. iii lines 43-54; P Par 1 col. iii no. 8.

42 Cumont 1937: 124; Otto 1905: 1. 89-90; Evans 1961: 191.

43 Neugebauer 1942: 237-239.

44 Borchardt 1899; Spiegelberg 1917: 1139-114t! to you by | New York University 
main of one and the same sacerdotal expert, not from documents of the Roman period, but from the inscriptions on the statues of two Egyptian astronomers of the Ptolemaic period. The statue of Harkhebi, from the third century BC, describes him as a 'hereditary prince and count... wise in the sacred writings, who observes everything observable in heaven and earth... who [among other things] announces rising and setting at their times, with the gods who foretell the future'. ${ }^{45}$ The other statue is of a 'star-watcher' of the templeofSobek at Khenty, whose skillsencompassed 'foretelling to man his future, telling him from his youth to his death', as well as announcing the years, months, and days and the courses of every star. ${ }^{46}$ Since both these inscriptions probably antedate the invention of the Hellenistic version of astrology, the kind of divination that they allude to is presumably allied to the Mesopotamian astral omens and horoscopes. A specific sign of Babylonian influence is Harkhebi's familiarity with the concept of the planetary exaltations in the zodiac.

At the moment there is little documentation from the Roman period papyri to help us with the identity of the astrologers within the temples. A fragmentary register of priests from late second-century Tebtunis ( $P$

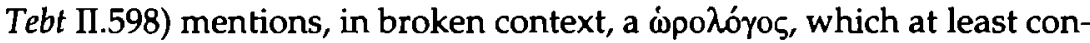
firms the existence of this title. Another possible Greek term for an astrologer occurs uniquely on an ostracon from MedinetMadi (OstrMed Mad 27). This Demotic text, to judge by the translation provided by the editors, is incomprehensible, but from the interspersed Greek words and numerals it resembles an astrological procedure text concerning the foretelling of a

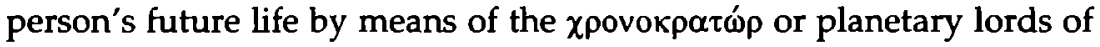

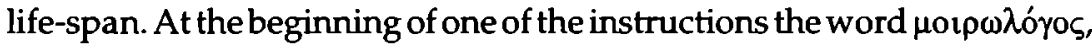
'destiny-teller' perhaps refers to the practitioner. In any case the eventual publication of the remaining ostraca from this site may further illuminate the operation of astrology and astrological training within the temple.

The bilingual character of this ostracon is symptomatic of a vacillation between the Greek and Egyptian languages among the astronomical and astrological documents of temple provenance. ${ }^{47}$ As is well known, the

45 Neugebauer \& Parker 1960-1969: 3. 214-216.

46 Daressy 1919: 276-278; Neugebauer \& Parker 1960-1969: 3. 215.

47 On the pronounced tendency of the ostraca from Medinet Madi to incorporate Greek words in Demotic texts, see Bondonti 1955; Bresciani \& Pintaualit 98. 
temples of provincial Egypt through the periods of Ptolemaic and Roman rule continued to be native Egyptian institutions, and as time progressed they became the last refuges of literacy in the Egyptian script. There is therefore a strong presumption that any Demotic astronomical or astrological document from the Roman period derives from a temple. ${ }^{48}$ These documents, moreover, account for a respectable fraction of the known Demotic corpus. A recent survey knows of 44 'astronomical/astrological' Demotic texts, both published and unpublished, which is nearly a twelfth of the total of 535 known 'literary or para-literary' Demotic texts. ${ }^{49}$

But among the known astronomical papyri those in Demotic represent only a minority: about 12 as compared to more than 50 in Greek, even before the new Greek texts from Oxyrhynchus are included in the count; and the fraction of Demotic horoscopes is smaller still. However, it would not be safe to infer from this statistic alone that the temple played a minor or historically insignificant role in the diffusion of astrology. The published horoscope 'notes' from Medinet Madi, after all, are in Greek. So is a tabular almanac (PSI inv 75D) pertaining to the years AD 48 through 52, which was excavated in the temple of Tebtunis; interestingly, the fragment not only preserves a line of Hieratic writing in the margin of the table, and evidently written before the table, but also the back of the roll was subsequently reused for a Demotic text apparently of religious significance. ${ }^{50}$ The chronological sandwiching of the astronomical table between two Egyptian texts makes it practically certain that the table was itself produced in the temple. It is quite plausible that some other Greek astronomical tables of unknown provenance also derive from Egyptian temples.

To be sure, I do not claim that every astronomical or astrological papyrus was written or used in a temple, or that this was the only place where one could get one's horoscope cast. In particular none of the evidence for astrology in the temples that I am aware of applies to dates after the second century. The third century was, after all, a period of decadence for the Egyptian temples, and in the long run it was the

48 For reservations about the rigorous application of this rule, see Tait 1992: 307-308.

49 Mertens 1992: 234.

50 Manfredi \& Neugebauer 1973. 
independent, and apparently secular, astrologers on whom the survival of practical astrology depended. ${ }^{51}$ Oxyrhynchus, a markedly hellenized town where Egyptian language and customs are poorly attested, has proved so far the richest source of astronomical and astrological papyri, none of which has a demonstrable sacerdotal connection.

Given that there were also independent astrologers working outside the temples, we are likely to find them in the authors of the comparatively rare deluxe horoscopes, such as $P$ Lond I.130 and $P$ Lond I.98, which set out the disposition of the heavens at the native's birth in an elaborate and pretentious prose text. $P$ Lond I.130, cast for a certain Hermon born in $\mathrm{AD} \mathrm{81}$, is one of only two known 'signed' horoscopes: in the margin at the end of the text is a colophon reading 'I, Titus Pitenius, made the computations as it is set out'. Through the veil of the Romanized name, which is an index of the social status of the astrologer, we can perhaps discern an Egyptian name form; and Titus Pitenius ascribes to the 'Egyptian men of old' the 'aeon-tables' that he used to compute the planetary positions to the degree and minute. The other horoscope, unsigned, is for someone born in AD 95. Very unusually, it follows the horoscope proper with a long text relating planetary configurations in the horoscope to predictions through the course of the native's life. Part way through, the language abruptly switches from Greek to Old Coptic, although reverting to Greek for section headings announcing the periods of life ruled by each planet in turn. Could the owner of this horoscope, whose hellenism may possibly be reflected in the copy of Hyperides' Funeral Oration on the back of the roll, read this Egyptian text? Or was the switch to Old Coptic for the later years of the man's life a deliberate device of obfuscation?

I conclude with a comparative note. The first mathematical predictive astronomy, and the one from which the arithmetical methods of the Egyptian papyri descend, was that of the Babylonian cuneiform texts, and these are known to us through numerous tablets from two temple archives, in Babylon and Uruk. ${ }^{52}$ We have documentary evidence that the production of these tables formed part of the duties of specially

51 Bagnall 1993: 261-268 (general decline of temples), 273-274 (evidence that wealthy Christians consulted astrologers in the late fourth century).

52 Neugebauer 1955. 
trained priests. ${ }^{53}$ That the end of this astronomy was astrological cannot be demonstrated from any known document or archaeological collocation of astronomical and astrological texts, but the same reasoning that we used for the Egyptian papyri is applicable here too: the numerical tables and almanacs are the only possible source known to us for the data in the Babylonian horoscopes, and vice versa it is difficult to imagine what other purpose this information could have served ${ }^{54}$ To be sure, there is also much in the Babylonian astronomical texts that has no known astrological application, and in general the scope of Mesopotamian astronomy seems to have been much broader than its Egyptian counterpart, witness the extensive observational records from Babylon.

In both cultures, then, some relationship appears to have existed between predictive astronomy, astrology, and the temple. I do not think this is a coincidence. Indeed, it is tempting to see in this hieratic milieu a channel through which both Mesopotamian astrological concepts and the ancillary predictive astronomy spread to Egypt; and we know that this transmission had begun in earnest by early Ptolemaic times. ${ }^{55}$ By the first century BC astrology had become infected with new Greek influences, manifested in the use of the concept of the celestial sphere, the imposition of a post-Aristotelian causal rationale for astrology, and even certain chronological conventions ${ }^{56}$ But at a more fundamental level the direction of flow may have been the other way, from Egyptian to Greek.

53 Rochberg 1993.

54 Rochberg 1989.

55 For an isolated Egyptian text, copied in the Roman period but reflecting Mesopotamian omen astrology of about the sixth century BC, see Parker 1959. Reymond 1983: 52-53 misrepresents, and makes a regrettable attempt to dismiss, Parker's demonstration (Parker 1959: 28-34, 53-54) of the Mesopotamian ancestry of the Egyptian astral omen texts.

56 Already in the early first century BC demotic eclipse canon (Neugebauer, Parker \& Zauzich 1981) one finds year numbering according to Callippic periods, a Greek invention - as was the four-year intercalation cycle for the Egyptian calendar proposed as early as 238 BC by Ptolemy III Euergetes (Orientis Graeci Inscriptiones Selectae I.56) and finally adopted as the 'Alexandrian' calendar. Goldstein \& Bowen 1989: 282-283, speculate that the 'Parker scheme', that is, the 25-year cycle of lunations on which the Egyptian festival calendar was based during late Hellenistic and Roman times, may also have beefiathelieristic inhovattion? 
For it was in Egypt, and not in Mesopotamia, that Greeks had the best exposure to the techniques of astral divination and predictive astronomy. In astronomy, then, as well as astrology, was Egypt the immediate source for many of the Babylonian elements in the Greek sciences?

\section{Bibliography}

E.B. Allen 1947. 'A Coptic Solar Eclipse Record', Joumal of the American Oriental Society 67, 267-269.

C.A.R. Andrews 1992. 'Unpublished Demotic Texts in the British Museum', Life in a Multi-Cultural Society: Egypt from Cambyses to Constantine and Beyond. Studies in Ancient Oriental Civilization 51. Chicago, 9-14.

D. Baccani 1989. 'Appunti per oroscopi negli ostraca di Medinet Madi', Analecta Papyrologica 1, 67-77.

Baccani 1992. Oroscopi greci: Documentazione papirologica. Messina.

R.S. Bagnall 1993. Egypt in Late Antiquity, Princeton.

L. Borchardt 1899. 'Ein altägyptisches astronomisches Instrument', Zettschrift für Ȧgyptische Sprache und Altertumskunde 37, 10-17.

G. Botti 1936. 'I Papiri ieratici e demotici degli scavi italiani di Tebtynis', Atti del IV Congresso internazionale di Papirologia. Milan, 217-223.

Botti 1955. 'Quello che ance l'egittologia deve a Carlo Anti' Anthemon. Scntti di Archeologia e di Antichità Classiche in Onore di Carlo Anti. Florence, 1-6.

E. Bresciani, S. Perngotti \& M.C. Betrò 1983. Ostraka Demotici da Narmuti, vol. 1. Pisa.

E. Bresciani \& R. Pintaudi 1987. 'Textes démotico-grecs et greco-démotiques des ostraca de Medinet Madi: un problème de bilinguisme', Aspects of Demotic Lexicography: Acts of the Second International Conference for Demotic Studies, Leiden, 19-21 September 1984, ed. S.P. Vleeming. Louvain, 123-126.

H. Brugsch 1856. Nouvelles recherches sur la division de l'année des anciens égyptiens, suivies d'une mémoire sur des observations planétaires consignées dans quatre tablettes égyptiennes en écriture démotique. Berlin \& Paris.

M. Chauveau 1992. 'Un traité d'astrologie en écriture démotique', Cahier de recherches de l'institut de papyrologie de Lille 14, 101-105.

F. Cumont 1937. L'Égypte des Astrologues. Brussels.

H.D. Curtis \& F.E. Robbins 1935. 'An Ephemeris of 467 A.D.', Publications of the Observatory of the University of Michigan 6.9, 77-100.

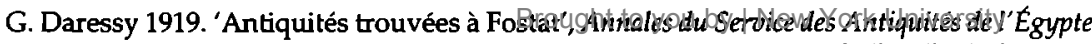
$18,276-278$. 
W.R. Dawson \& E.P. Uphill 1972. Who was Who in Egyptology. 2nd ed. London.

S. Donadoni 1955. 'Il greco di un sacerdote di Narmuthis', Acme 8. 73-83.

J.A.S. Evans 1961. 'A Social and Economic History of an Egyptian Temple in the Greco-Roman Period', Yale Classical Studies 17, 143-283.

J.K. Fotheringham 1935. Review of Curtis \& Robbins 1935. Classical Review 49, 242.

P J. Frandsen et al. 1991. The Carlsberg Papyri 1: Demotic Texts from the Collection. Copenhagen.

B.R. Goldstein \& A.C. Bowen 1989. 'On Early Hellenistic Astronomy. Timocharis and the First Callippic Calendar', Centaurus 32, 272-293.

T.G.H. James 1982. Excavating in Egypt: The Egypt Exploration Society 1882-1982. London/Chicago.

A. Jones 1994. 'An Astronomical Ephemeris for A.D. 140: P. Harris I.60', Zeitschnft fur Papyrologie und Epigraphik 100, 59-63.

J. Krüger 1990. Oxyrhynchos in der Kaiserzeit: Studien zur Topographie und Literaturrezeption. Frankfurt.

M. Marfredi \& O. Neugebauer 1973. 'Greek Planetary Tables from the Time of Claudius', Zettschrift für Papyrologie und Epigraphtk 11, 101-114.

J. Mertens 1992. 'Bibliography and Description of Demotic Literary Texts: A Progress Report', Life in a Multi-Cultural Society: Egypt from Cambyses to Constantine and Beyond. Studies in Ancient Oriental Civilization 51. Chicago, 233-235.

O. Neugebauer 1939. 'Egyptian Astronomy', Nature 143, 115-117.

Neugebauer 1942. 'Egyptian Planetary Texts', Transactions of the American Philosophical Society 32.2, 209-250, with Plates 1-27.

Neugebauer 1943. 'Demotic Horoscopes', Journal of the American Oriental Society 63, 115-126, with Plates $1 \& 3$.

Neugebauer 1949. 'The Astronomical Treatise P. Ryl. 27', Det Kongelige Danske Videnskabernes Selskab, Historisk-Filologiske Meddelelser 32.2.

Neugebauer 1952. 'Tamil Astronomy', Osiris 10, 252-276.

Neugebauer 1955. Astronomical Cuneiform Texts. 3 vols. London.

Neugebauer 1962. 'Astronomical Papyri and Ostraca: Bibliographical Notes', Proceedings of the American Philosophical Society 106, 383-391.

Neugebauer 1975. A History of Ancient Mathematical Astronomy. 3 vols. Berlin etc.

O. Neugebauer \& R.A. Parker 1960-1969. Egyptian Astronomical Texts. 3 vols. in 4. Providence.

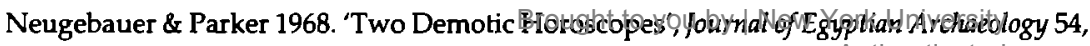
231-235. 
O. Neugebauer, R.A. Parker \& K.-T. Zauzich 1981. 'A Demotic Lunar Eclipse Text of the First Century B.C.', Proceedings of the American Philosophical Society 125, 312-327.

O. Neugebauer \& H.B. van Hoesen 1959. Greek Horoscopes. Memoirs of the American Philosophical Society 48. Philadelphia.

Neugebauer \& van Hoesen 1964. 'Astrological Papyri and Ostraca: Bibluographical Notes', Proceedings of the American Philosophical Soctety 108, 57-72.

W. Otto 1905. Pnester und Tempel ım hellentstıschen Ägypten. 2 vols. Leipzig \& Berlin.

R.A. Pack 1965. The Greek and Latin Literary Texts from Greco-Roman Egypt. 2nd ed. Ann Arbor.

R.A. Parker 1959. A Vienna Demotic Papyrus on Eclipse and Lunar Omına. Providence.

Parker 1984. 'A Horoscopic Text in Triplicate', Grammata Demotica. Festschrift für Eric Luddeckens zum 15 Junt 1983, ed. H.J. Thissen \& K.-T. Zauzich. Würzburg, 141-143.

E.A.E. Reymond 1976. From the Contents of the Libraries of the Suchos Temples in the Fayyum. Part I: A Medical Book From Crocodilopolis. Vienna.

Reymond 1983. 'Demotic Literary Works of Graeco-Roman Date in the Rainer Collection of Papyri in Vienna', Festschrift zum 100-jährigen Bestehen der Papyrussammlung der Ósterreichischen Nationalbibliothek: Papyrus Erzherzog Rainer (P. Rainer Cent.). 2 vols. Vienna, 42-60.

F. Rochberg 1989. 'Babylonian Horoscopes and their Sources', Onentalia 58, 102-123, with Plates I-II.

Rochberg 1993. 'The Cultural Locus of Astronomy in Late Babylonua', Die Rolle der Astronomie in den Kulturen Mesopotamiens, ed. H.D. Galter. Grazer Morgenlandische Studien 3. Graz, 31-45.

P.J. Sijpesteijn 1979. 'Some Remarks on Roman Dates in Greek Papyri', Zeitschrift fur Papyrologie und Epigraphik 33, 229-240.

R W Sloley 1936. Review of Curtis \& Robbins 1935. Journal of Egyptian Archaeology 22, 218-219.

W. Spiegelberg 1917. 'Varia', Zeitschrift für Agyptische Sprache und Altertumskunde 53, 91-115.

H. Stobart 1855. Egyptian Antiquities collected on a voyage made in Upper Egypt in the years 1854 \& 1855 and published by Rev $v^{d}$. H. Stobart. M.A. Queen's College Oxford. Paris \& Berlin.

N.M. Swerdlow 1993. 'Otto E. Neugebauer', Proceedings of the American Philosophical Society $137,137-165$.

W.J. Tait 1977. Papyrifrom Tebtunis in Egyptian and in Greek (P. Tebt. Tait). London.

Tait 1992. 'Demotic Literature and Egyptian Society', Life in a Multi-Cultural Society: Egypt

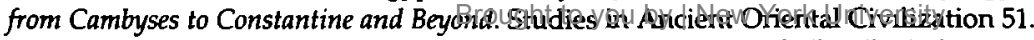
Chicago, 303-310. 
E.G. Tumer 1952. 'Roman Oxyrhynchos', Journal of Egyptian Archaeology 38, 78-93.

Turner 1956. 'Scribes and Scholars of Oxyrhynchos', Akten des VIII. Internationalen Kongresses für Papyrologie, Wien 1955. Mitteilungen aus der Papyrussammlung der Oesterreichischen Nationalbibliothek, N.S. 5. Vienna, 141-146.

A. Vogliano 1938. 'Rapporto preliminare della IV campagna di scavo a Medînet Madî', Annales du Service des Antiquités de l'Égypte 38, 533-549.

A. Volten 1951. 'The Papyrus-Collection of the Egyptological Institute of Copenhagen', Archıv Orientální 19, 70-74. 
Brought to you by | New York University 